\title{
COMPARATIVE ANALYSIS OF VOCATIONAL TRAINING SYSTEMS IN THE LIGHT OF
} EU GUIDELINES

\author{
Ágnes Stomp, Marianna Móré \\ University of Debrecen, Faculty of Health, Institute of Social and Sociological Sciences, \\ Debrecen, Hungary \\ stompagnes@gmail.com \\ more.mariann@foh.unideb.hu
}

\begin{abstract}
Continuous development of education and training programmes in the European Union is a key factor in enhancing cooperation at European level. Today, economic and social changes are taking place in the world, which is why vocational training is seen as a tool to prepare people for a changing world of work, improving employability and competitiveness. Vocational education and training must adapt to changes affecting the economy, society and the labour market. Vocational education and training (VET) policy has been a national, autonomous area of the Member States for decades, but the issue of VET has increasingly been given priority in the process of European economic unification. At the Lisbon Summit, the European Council recognised the important role of education as an integral part of economic and social policies, which is an important tool for increasing the European Union's competitiveness. European cooperation in VET has been promoted by the three common European instruments created as a result of Copenhagen process: the European Qualifications Framework (EQF), the European Quality Assurance Reference Framework for Vocational Education and Training (EQAVET) and the European Credit System for Vocational Education and Training (ECVET), which are progressively integrated in their VET systems by the Member States. The aim of these instruments is to support recognition between European VET systems, to promote lifelong learning and mobility and to improve learning experiences. The aim of our study is to explore with a comparative study, to what extent and manner the V4 Member States (Czech Republic, Hungary, Poland, Slovakia) have integrated EQF, EQAVET and ECVET transparency instruments into their national vocational training systems and to what extent the transformations are in line with EU objectives.
\end{abstract}

Keywords: EU vocational education policy; national vocational education system; tools for transparency

JEL Classification: 121

\section{Generally Introduction or Background}

Vocational education and training policy has been a national, autonomous area of the Member States for decades, but the issue of VET has been continually present from the outset and has been given increasing priority in the process of economic unification in Europe. The Lisbon Strategy of 2000 drew attention to the fact that the transition to a knowledge-based economy requires modern and adaptable vocational training, in which the quality of vocational education and training plays a key role (European Commission, 2019). This strategy formed the basis for the Copenhagen Declaration adopted in 2002, in which EU Member States adopted common priorities and strategies to promote European-level frameworks for the recognition of skills and qualifications, which can be achieved by developing and strengthening vocational training. (European Commission, 2018). The effectiveness of the Copenhagen process is reflected in the three common European instruments established between 2008 and 2009: the European Qualifications Framework 
(EQF), the European Quality Assurance Reference Framework for Vocational Education and Training (EQAVET) and the European Credit System for Vocational Education and Training (ECVET), which are also referred to as the instrument of transparency (The Bruges Communiqué, 2010). These tools provide an opportunity for the Member States to open up their VET systems to each other and recognise learners' learning outcomes acquired in different learning environments (Markowitsch, J., \& Hefler, G., 2019). The common feature of the three instruments is that the principle of learning outcomes is applied in the process of education, assessment and recognition in the VET system (European Commission, 2019). The learning outcome is a description of competence that defines the output requirements that can be achieved through learning in the field of knowledge, ability and responsibility (Balla et al, 2020). The introduction and application of the interconnected instruments in a coordinated manner will promote qualifications based on learning outcomes to meet labour market needs more effective as well as better transparency, transferability, recognition of qualifications and European mobility (Balla et al, 2020).

\section{Applied methods}

The aim of our study is to provide a comparative analysis of the national VET systems of the four countries in terms of the use of transparency instruments. As a research method, we have chosen content analysis, which is suitable for making causation and comparative analyses. The documents of the European Parliament and the Council related to vocational training, the Official Journal of the European Union and the publicly available country evaluation studies of the European Commission and the European Centre for Vocational Training and Development (CEDEFOP) have been considered as documents. As a research analysis, the appearance of the EQF, EQAET and ECVET tools and their country-specific elements were identified. We examined the appearance of the instruments in four Member States of the European Union so-called Visegrad Fours (V4 - Czech Republic, Hungary, Poland, Slovakia).

\section{Reflection of the EU VET policy in national reforms in the Visegrad Four countries}

In this article, we present a comparative analysis of the VET systems of four neighbouring countries - the Czech Republic, Hungary, Poland and Slovakia - with the European VET policy in the light of EQF, EQAVET and ECVET, which started from a very similar point due to the common historical past. Analysing the starting point for all four countries, vocational education was carried out within the framework of a centrally planned market economy until 1989. Until 1989, VET schools were managed in cooperation with companies, where students' participation was very high. (Dębowski, H., \& Stęchły, W. 2015). The collapse of the Soviet system led to social, political and economic changes affecting VET and its system (Wiśniewski \& Zahorska, 2020). During the economic transition, a number of state-owned companies operating vocational schools have ceased to exist. The pupils opted for general secondary education as opposed to vocational education due to the apparent lack of prospects of vocational training (Szulc, W., et al, 2019). These two factors combined led to a decrease in the popularity of VET (Markowitsch, J., \& Hefler, G. 2019) and a weakening of the link between VET and labour market needs (Chłon-Domińczak et al, 2012). Since the late 2000s, the significance of vocational education and training and the creation of an attractive vocational education offer to young people have become national priorities (Dębowski, H., \& Stęchły, W. 2015). The accession of the Czech Republic, Hungary, Poland and Slovakia to the European Union on 1 May 2004 had a major impact on national vocational education and training systems. The issue of VET has also been given increasing 
priority in the EU and has been translated into educational policy, guidelines and recommendations. As members of the European Union, the four countries examined have progressively adopted these guidelines and recommendations into their national vocational training systems (Dębowski, H., \& Stęchły, W., 2015).

The four countries analysed faced a number of challenges of integrating the EQF, EQAVET and ECVET instruments into their national VET systems. The main task of the decisionmakers of the countries was to define and create the necessary conditions for the integration of the instruments by creating the right legislative environment that ensures the future application of the instruments at national, regional, local and sectoral levels. The establishment of an adequate institutional infrastructure to ensure the integration of instruments, while preserving national specificities, can be considered a major challenge for countries. New reforms and programmes may also entail a change in the roles and responsibilities of the stakeholders. VET professionals, policy makers, social partners, researchers, heads of educational institutions, businesses and sectoral organisations have a significant role to play in preparing education and training systems for the implementation and use of tools. A high degree of stakeholder commitment and adaptability is also needed in order to integrate the instruments successfully.

In the following we will examine below the extent and manner to which the four countries have integrated the EQF, EQAVET and ECVET instruments into their VET systems, in line with the EU guidelines, in order to contribute to the Copenhagen objectives.

\subsection{The vocational education and training system in the light of the EQF}

One of the major objectives of the European Union is to contribute to the modernisation of education and training systems, to increase the social integration, mobility and employability of learners and workers (de Paor, C., 2018). As a means of achieving this objective, the European Council established the European Qualifications Framework (EQF), which serves as a referencing tool between the different qualifications systems and levels of the Member States (Bohlinger, 2019). The EQF aims to improve the transparency, comparability and mobility of qualifications acquired by individuals (Council of the EU, 2017). The EQF includes all attainable levels of education from primary to the highest education such as: all levels of generally acquired qualifications, vocational training and university education, as well as qualifications which can be obtained in initial and continuing training. The structure and content of European education and training systems are complex and diverse. For qualifications to be comparable across countries, the EQF framework considers it necessary to move on to learning outcomes, characterised by descriptors of knowledge, skills and competence (Farkas, 2013). The new framework refers to learning outcomes as meaning what a learner knows, understands and is able to do after completing the learning process by obtaining a qualification, so classification in the EQF framework does not take into account the duration of the training (Farkas, 2013). Each country has allocated its training programmes to EQF levels according to the level of learning outcomes that can be obtained during the training programme. This makes it possible to take into account the specificities of national vocational training systems (Derényi, 2019). The vocational education and training systems of the four countries we examined include the following levels in line with the EQF (Cedefop, 2019a; 2019b; 2019c; 2019d): 


\begin{tabular}{|c|c|c|c|c|}
\hline & $\begin{array}{l}\text { The Czech } \\
\text { Republic }\end{array}$ & Poland & Hungary & Slovakia \\
\hline $\begin{array}{c}\text { EQF } \\
1\end{array}$ & Nursery school & Nursery school & Nursery school & Nursery school \\
\hline $\begin{array}{c}\text { EQF } \\
2\end{array}$ & $\begin{array}{l}\text {-Lower } \\
\text { secondary } \\
\text { progr. } \\
\text {-Progr. for SEN } \\
\text { learners }\end{array}$ & $\begin{array}{l}\text {-Lower secondary } \\
\text { progr. } \\
\text {-Work preparation } \\
\text { classes for SEN } \\
\text { learners } \\
\text {-Special job } \\
\text { training progr. for } \\
\text { SENlearners }\end{array}$ & $\begin{array}{l}\text {-Lower secondary } \\
\text { progr. } \\
\text {-Lower secondary } \\
\text { progr. for SEN } \\
\text { learners } \\
\text {-Bridging progr. }\end{array}$ & $\begin{array}{l}\text {-Lower secondary progr. } \\
\text {-Bridging progr. } \\
\text {-Lower sec.progr. } \\
\text {-Performing arts progr. } \\
\text {-VET progr. for SEN } \\
\text { learners }\end{array}$ \\
\hline $\begin{array}{c}\text { EQF } \\
3\end{array}$ & $\begin{array}{l}\text {-School-based } \\
\text { VET }\end{array}$ & $\begin{array}{l}\text {-First stage } \\
\text { sectoral progr. }\end{array}$ & $\begin{array}{ll}\text {-Practice } & \text { oriented } \\
\text { VET progr. } & \end{array}$ & $\begin{array}{l}\text {-School-based progr. } \\
\text {-Practiceoriented upper } \\
\text { secondary VET progr. }\end{array}$ \\
\hline $\begin{array}{c}\text { EQF } \\
4\end{array}$ & $\begin{array}{l}\text {-Technical and } \\
\text { lyceum progr. } \\
\text {-General progr. } \\
\text {-Follow-up } \\
\text { progr. } \\
\text {-Performing arts } \\
\text { progr. }\end{array}$ & $\begin{array}{l}\text {-General progr. } \\
\text {-Second stage } \\
\text { sectoral progr. } \\
\text {-Vocational upper } \\
\text { secondary progr. }\end{array}$ & $\begin{array}{l}\text {-Upper secondary } \\
\text { progr. } \\
\text {-School-based } \\
\text { theory-focused VET } \\
\text { progr. } \\
\text {-Follow-up progr. }\end{array}$ & $\begin{array}{l}\text {-School-based progr. } \\
\text {-Upper secondary progr. } \\
\text {-Performing arts progr. } \\
\text {-Progr. leading to a 2nd } \\
\text { VET qualification }\end{array}$ \\
\hline $\begin{array}{c}\text { EQF } \\
5\end{array}$ & $\begin{array}{l}\text {-Performing arts } \\
\text { progr. }\end{array}$ & $\begin{array}{l}\text {-Post-secondary } \\
\text { school-based } \\
\text { progr. } \\
\text {-College progr. }\end{array}$ & $\begin{array}{l}\text {-Higher education } \\
\text { VET progr. } \\
\text {-School based } \\
\text { practice progr }\end{array}$ & $\begin{array}{l}\text {-Higher professional } \\
\text { progr. } \\
\text {-Specialising progr. } \\
\text {-Performing arts progr. }\end{array}$ \\
\hline $\begin{array}{c}\text { EQF } \\
6-8\end{array}$ & $\begin{array}{l}\text { Academic } \\
\text { higher } \\
\text { education }\end{array}$ & $\begin{array}{l}\text { Academic higher } \\
\text { education }\end{array}$ & $\begin{array}{l}\text { Academic higher } \\
\text { education }\end{array}$ & $\begin{array}{l}\text { Academic higher } \\
\text { education }\end{array}$ \\
\hline
\end{tabular}

Source: Own editing based on Cedefop's 2019 data

Assessing Table 1, it can be stated that the Czech, Hungarian, Polish and Slovak national qualification frameworks follow the level structure of the EQF, namely each has got eight levels. Analysing the basic system of VET in all four countries, formal VET leads to four levels of qualification (EQF 2-5) at national level, which are the same as those set out in the European Qualifications Framework (EQF). By using the EQF as a European transparency tool in the development of the national VET system, the Czech Republic, Hungary, Poland and Slovakia support the promotion of transnational mobility (The Bruges Communiqué, 2010; Chłon-Domińczak A. et al, 2019; Cedefop, 2019a; 2019b; 2019c; 2019d).

\subsection{The vocational education and training system in the light of the EQAVET}

The Recommendation on a European Quality Assurance Reference Framework for Vocational Education and Training (EQAVET) was adopted in 2009 with the aim of improving and increasing the quality of vocational education and training (European Parliament and Council, 2009). The EQAVET framework provides significant assistance to Member States in documenting, developing, monitoring, evaluating and improving quality management practices (Farkas, 2013). The Recommendation does not require Member States to apply a specific quality assurance system, but sets out indicators and descriptors (European Commission, 2019).

The EQAVET recommendation contains the following two technical elements: 
- A quality cycle, which forms the basis of evaluation for the providers and VET system-level in the evaluation process.

- Indicators and descriptors, which define indicative descriptors and quality criteria at provider-level and system-level (European Commission, 2019).

These elements can also be used for self-evaluation and external evaluation. It can be used in accordance with national legislation and practices, so it is up to the Member States to decide which indicators to be used in the evaluation process (Farkas, 2013). Out of the four countries we examined, Poland has set up its national quality assurance system for its VET system in accordance with the EQAVET framework. In Hungary the national quality assurance system for VET will be set up according to the EQAVET framework by 2022. Analysing the case of the Czech Republic, it can be concluded that its national quality assurance system has been developed independently of the EQAVET system, but it is aligned with the EQAVET quality cycle, indicators and descriptors. Similarly to the Czech Republic, Slovakia has developed a national quality assurance system, which is not aligned with the quality cycle but it is relevant to indicators and descriptors (European Commission, 2019). The Table 2 below compares the quality assurance measures of VET systems of the four countries examined at provider-level and system-level (Cedefop, 2019a; 2019b; 2019c; 2019d).

Table 2: Quality assurance measures in the countries' VET systems

\begin{tabular}{|l|l|l|}
\hline \multicolumn{1}{|c|}{$\begin{array}{c}\text { Quality assurance measure } \\
\text { at provider-level }\end{array}$} & $\begin{array}{c}\text { Quality assurance measure } \\
\text { at system-level }\end{array}$ \\
\hline $\begin{array}{l}\text { Czech } \\
\text { Republic }\end{array}$ & $\begin{array}{l}\text { Self-evaluation } \\
\text {-for IVET and CVET up to 2011 annually }\end{array}$ & $\begin{array}{l}\text { External evaluation } \\
\text {-for IVET and CVET annually }\end{array}$ \\
\hline Poland & $\begin{array}{l}\text { Internal evaluation } \\
\text {-for IVET annually }\end{array}$ & $\begin{array}{l}\text { External evaluation } \\
\text {-for IVET and CVET annually }\end{array}$ \\
\hline Hungary & $\begin{array}{l}\text { Self-evaluation } \\
\text {-for IVET every two years } \\
\text { Trainer's evaluation every three years }\end{array}$ & $\begin{array}{l}\text { External evaluation } \\
\text {-for IVET and CVET } \\
\text { every four years }\end{array}$ \\
\hline Slovakia & $\begin{array}{l}\text { The school development strategy is } \\
\text { issued annually by the head of the } \\
\text { institution and its assessment must be } \\
\text { presented to the school council }\end{array}$ & $\begin{array}{l}\text { External evaluation } \\
\text {-for IVET annually }\end{array}$ \\
\hline
\end{tabular}

Source: Own editing based on Cedefop's 2019 data

Analysing the four examined countries' quality assurance measures at provider-and systemlevel, it can be stated that the quality assurance measures of the Czech Republic, Poland and Hungary are very similar. The quality assurance systems of all three countries require self-evaluation to be carried out only for IVET institutions, but external evaluation is required for both IVET and CVET institutions. However, there is a significant difference in the frequency of carrying out evaluations. While the Czech Republic and Poland carry out evaluation at provider-and system-level annually, Hungary carries out self-evaluation every two years and external evaluation every four years. We consider it important to emphasize that Hungary also introduces trainer's evaluation at provider-level, during which the salaries of trainers may vary from one person to another according to their performance. In the case of Slovakia, the national quality assurance system requires external evaluation to be carried out only for IVET institutions it does not require it for CVET institutions. With regard to quality assurance measures at provider-level, it can be concluded that this completely differs from the other three countries examined. Self-evaluation is not considered necessary, but rather a school development strategy is defined and evaluated (European Commission, 2019). 


\subsection{The vocational education and training system in the light of the ECVET}

The development and recognition of people's knowledge, skills and competences play a significant role in the competitiveness of the European Union and for employment. In 2004, the Council issued a recommendation giving high priority to the development and implementation of the European Credit System for VET, along the line with the European Credit Transfer System for Higher Education (ECTS) (Balla et al., 2020). As a result, the Recommendation on the European Credit System for VET (ECVET) was adopted in 2009 to facilitate the recognition and transfer of learning outcomes achieved by the applicant through different educational and learning pathways between vocational education institutions of the Member States throughout Europe (European Parliament and Council, 2009). ECVET is a technical framework for the transfer, recognition and accumulation of learners' learning outcomes for the purpose of obtaining a qualification (Dębowski, H., \& Stęchły, W., 2015). ECVET applies a modular approach to VET, meaning that subjects are described using units of learning outcomes, taking into account national and sectoral specifications (de Paor, C., 2018; European Commission, 2019).

The ECVET tools and methodology include the following elements:

1. Units of learning outcomes: The requirements for qualifications are expressed as learning outcomes which are defined in terms of knowledge, skills and competence. Learning outcomes are divided into learning units that receive ECVET points. A qualification comprises several unit and the qualification consists of the total number of units (Antonazzo, 2020).

2. Transfer and accumulation of learning outcomes, ECVET-partnerships: the credit system allows the accumulation, validation and recognition of learning outcomes gained in formal, non-formal or informal settings and transfer them from one institution to another (Poczmańska, A., \& Stęchły, W., 2020). Within the framework of ECVET partnerships, two or more cooperating institutions conclude a memorandum of understanding setting out the legal and procedural framework for the transfer of learning outcomes.

3. Learning agreement and personal transcript: it promotes international and national learner mobility between VET institutions, with the aim of recognizing learning outcomes achieved during mobility without prolonging the course (Le Mouillour, 2012). The following two agreements are used for mobility:

- Learning Agreement (LA): an agreement between the cooperating VET institutions and the learner specifying the learning outcomes and units to be achieved by the learner during the mobility period.

- Personal Transcript: it comprises the learners' evaluated learning outcomes, units and ECVET points (Európai Parlament és Tanács, 2009; Balla et al, 2013; Balla et al, 2020; Dębowski, H., \& Stęchły, W., 2015). The introduction of ECVET is based on voluntary decisions by Member States. The ECVET Recommendation provides a general framework for Member States, which means that ECVET can be adapted to their national VET systems in many ways. Since there is no specific way of implementing ECVET, there are significantly different cases of introducing ECVET into the national VET between Member States (Farkas, 2013).

Table 3 below summarises the scope of implementation of ECVET instruments and principles in the four countries examined (European Commission 2019). 
Table 3: Scope of implementation of the ECVET principles in the four countries

\begin{tabular}{|l|l|l|l|l|}
\hline & $\begin{array}{l}\text { The Czech } \\
\text { Republik }\end{array}$ & Poland & Hungary & Slovakia \\
\hline $\begin{array}{l}\text { 1. Units of learning } \\
\text { outcomes }\end{array}$ & $\begin{array}{l}\text { Qualifications } \\
\text { based on } \\
\text { learning } \\
\text { outcomes }\end{array}$ & $\begin{array}{l}\text { Qualifications } \\
\text { based on } \\
\text { learning } \\
\text { outcomes }\end{array}$ & $\begin{array}{l}\text { Qualifications } \\
\text { based on } \\
\text { learning } \\
\text { outcomes }\end{array}$ & $\begin{array}{l}\text { Qualificatio } \\
\text { ns based on } \\
\text { subjects }\end{array}$ \\
\hline $\begin{array}{l}\text { 2. Transfer, } \\
\text { accumulation } \\
\text { learning outcomes, } \\
\text { ECVET-partnerships }\end{array}$ & $\begin{array}{l}\text { Credits used in } \\
\text { certain } \\
\text { qualifications }\end{array}$ & $\begin{array}{l}\text { Credit system } \\
\text { in place, but } \\
\text { not applied }\end{array}$ & $\begin{array}{l}\text { No credit } \\
\text { system }\end{array}$ & $\begin{array}{l}\text { No credit } \\
\text { system }\end{array}$ \\
\hline $\begin{array}{l}\text { 3.Learning Agreement } \\
\text { and Personal Transcript }\end{array}$ & Widely used & $\begin{array}{l}\text { Applied but not } \\
\text { national } \\
\text { priority }\end{array}$ & Widely used & Widely used \\
\hline
\end{tabular}

Source: Own editing based on Cedefop's 2019 data

Analyzing the table above, it can be stated that ECVET instruments are used in some form by all four countries, although in different extent. As regards units of learning outcomes, it can be noted that the Czech Republic, Poland and Hungary describe qualifications in their learning outcomes and units. In Slovakia, the description of qualifications is still based on subjects, but the introduction of a philosophy of learning outcomes is supported. This is reflected in the fact that some schools are already working with learning outcomes and units when finalising curricula, as schools are autonomous in finalising curricula. The credit system for the transfer and accumulation of learning outcomes has only been fully developed by Poland, but it is not applied. The Czech Republic already uses credits in some qualifications, but plans to develop the credit system. In Hungary and Slovakia, the credit system proposed by ECVET has not been developed. However, for all four countries, it should be noted that it is possible to transfer, collect and accumulate learning outcomes acquired in different non-formal and informal settings, but this is done specifically at national level according to their training system characteristics. As regards the Learning Agreement and Personal Transcript, it is clear from the table that three of the four countries use the documents widely in learner mobility. According to a Cedefop's 2019 study, in the Czech Republic, Hungary and Slovakia ECVET is used primarily for international mobility, in which they promote quality, cooperation and improve the recognition of learning outcomes achieved abroad. In Poland, international mobility is not a national priority but has shown increasing interest in its development (Cedefop, 2019a; 2019b; 2019c; 2019d).

\section{In conclusion}

In the European Union, the issue of VET has increasingly been given priority in the process of economic unification. An active, coherent EU VET policy can only be referred to the Lisbon Strategy of 2000 . The Copenhagen process of 2002 has already emphasised the development of a system that supports the recognition of professional qualifications between Member States. The success of the Copenhagen process is reflected in the three common European transparency instruments: EQF, EQAVET and ECVET established between 2008 and 2009, the common objective of which is the recognition, transparency of qualifications between education systems in Europe, and the promotion of lifelong learning and mobility. The aim of our study was to explore what extent and manner The Czech Republic, Poland, Hungary and Slovakia have integrated these instruments into their VET systems. In the four countries examined, formal vocational education and training leads to four qualification levels at national level, which have been developed in accordance with the EQF guidelines. This ensures the transparency of vocational qualifications and mobility, as the same levels 
are applied to the classification of professional qualifications. The national quality assurance system of the VET system of Poland and Hungary has been developed in accordance with the EQAVET framework, while the quality assurance system of the Czech Republic and Slovakia has been developed independently of the EQAVET system, but is aligned with the principles of EQAVET. There were many similarities between the Czech, Polish and Hungarian quality assurance measures, although there was a significant difference in the frequency of carrying out evaluations. Slovakia's institutional quality assurance measure differs from those of the other three countries, as they develop and evaluate a school development strategy instead of self-assessment. Out of the three instruments, the ECVET credit system recommendations have only been partially implemented in the Czech Republic, Hungary and Slovakia. In the case of Poland only, it can be stated that the ECVET tool and methodology have been fully integrated into the national VET system, although the credit system has been developed but is not used. One reason for this may be the lack of a single credit point calculation system, which may make it difficult or hindering the transfer and recognition of learning outcomes acquired during the learning process between Member States. Instead, ECVET is seen as a mobility tool by the countries analysed, with which they successfully contribute to the development of mobility. The Czech Republic, Poland and Hungary describe vocational qualifications on the basis of learning outcomes, which are essential for achieving the objective of the three instruments. In Slovakia, vocational qualifications are still subject-based, but some schools have already adopted the learning outcomes-based approach. Overall, the four countries examined have made significant progress in integrating the EQF, EQAVET and ECVET instruments into their national VET systems, thereby contributing to the achievement of the Copenhagen targets.

\section{References}

1. Antonazzo, L., Weinel, M., \& Stroud, D. (2020) Analysis of cross-European VET frameworks and standards for sector skills recognition. Blueprint"New Skills Agenda Steel"Industry-driven sustainable European Steel Skills Agenda and Strategy ESSA

2. Balla, Á., Farkas, É., Lukács, J.,, Marton, J., Molnárné Stadler K.,, Palencsárné Kasza, M., \& Rozmán, É. (2020) Az ECVET Szakértöi Hálózat tevékenysége és szerepe a szakképzés korszerüsítésében 2012-2020. Tempus Közalapítvány.

3. Balla, Á., Lukács, J., Nagy, Zs., \& Szebeni, K. (2013) Rugalmas és átjárható szakképzés Dilemmák és lehetőségek az Európai Szakoktatási és Szakképzési Kreditrendszer (ECVET) eszközeinek hazai alkalmazására. HOPPÁ Disszeminációs füzetek 43. Tempus Közalapítvány

4. Bohlinger, S. (2019) Ten years after: the 'success story' of the European qualifications framework, Journal of Education and Work, 32:4, 393-406, DOI: 10.1080/13639080.2019.1646413

5. Cedefop (2019a) Vocational education and training in Europe: Hungary, National Office of VET and Adult Learning, Available: https://www.cede fop.europa.eu/en/tools/vet-in-europe/systems/hungary [13.10.2020]

6. Cedefop (2019b) Vocational education and training in Europe: Czechia, National Institute for Education; National Training Fund, Available: https://www.cedefop.euro pa.eu/en/tools/vetineurope/systems/czech-republic [13.10.2020]

7. Cedefop (2019c) Vocational education and training in Europe: Poland, Educational Research Institute, Available: https://www.cedefop.europa.eu/en/tools/vet-in-europe/systems/poland [13.10.2020]

8. Cedefop (2019d) Vocational education and training in Europe: Slovakia, State Institute of VET, Available: https://www.cedefop.europa.eu/en/tools/vet-in-europe/systems/slovakia [13.10.2020]

9. Chłoń-Domińczak, A., Dębowski, H., Drogosz-Zabłocka, E., Dybaś, M., Holzer Żelażewska,D., Maliszewska, A., Paczyński, W. Podwójcic, K, Rucińska, M., Stęchły, W., Tomasik, M., TrawińskaKonador, K., Ziewiec, G. (2012). Edukacja zawodowa w Polsce [Vocational education in Poland].In: M. Federowicz and A. Wojciuk (eds.), Kontynuacjaprzemian. Raport o stanie edukacji 2011 [The changes continue. Report

on the State of Education 2011] (pp. 169-249) Warszawa: Instytut Badań Edukacyjnych 
10. Chłoń-Domińczak, A., Holzer-Żelażewska, D., Maliszewska, A., Przybylska, B., and Wasilewska, O. (2019) Vocational education and training in Europe - Poland. Cedefop ReferNet VET in Europe reports $2018.2 \quad$ Available: http://libser ver.cedefop. europa.eu/vetelib/2019/Vocational_Education_Training_Europe_Poland_2018_Cedefop_ReferNet.p df [14.10.2020]

11. Council of the EU (2017). Recommendation of the European Parliament and of the Council of 23 April 2008 on the Establishment of the European Qualifications Framework for lifelong learning (C 189/15). Available: https://eur-lex.europa. eu/legal -content [8.01.2021]

12. de Paor, C. (2018) Supporting change in VET: Teachers' professional development and ECVET learner mobility. Empirical Research in Vocational Education and Training, 10(1), 1-13.

13. Dębowski, H., \& Stęchły, W. (2015) Implementing ECVET principles. Reforming Poland's vocational education and training through learning outcomes based curricula and assessment. In Warsaw Forum of Economic Sociology Vol. 6, No. 12, pp. 57-88.

14. Derényi, A. (2019) Képesítési keretrendszerek fejlödése itthon és a világban. Available:https://ofi.oh.gov.hu/publikacio/kepesitesi-keretrendszerek-fejlodese-itthon -es-vilagban [08.05.2021]

15.Európai Parlament és Tanács (2009) AZ Európai Parlament és a Tanács Ajánlása az Európai szakoktatási és szakképzési kreditrendszer (ECVET) létrehozásáról, Az Európai Unió Hivatalos Lapja. Tájékoztatások és közlemények. ISSN 1725-518X C 155. 52. évfolyam, 2009. július 8. Available: https://eur-lex.europa.eu/legal-content/HU/TXT/PDF/?uri=OJ:C:2009:155: FULL\& fr om=PL [17.10.2020]

16. European Commission (2018) A quick guide to EU action on vocational education and training, European Commission, Available: http://ec.europa.eu/social/Blob Servl et?docld= 20253\& langl d=en [18.10.2020]

17. European Commission (2019) Study on EU VET instruments (EQAVET and ECVET), European Commission Available: https://op.europa.eu/en/publication-detail/-/publication/205aa0ac-460d-11e9a8ed-01aa75ed71a1/la nguage-en [15.10.2020]

18. European Parliament and Council (2009) Council Recommendation on the European Quality Assurance Reference Framework for VET. Official Journal of the European Union 8.7.2009 C 155/1 Available: https://eur-lex.europa.eu/

LexUriServ /LexUriServ.do?uri=OJ:C:2009:155:0001:0010:EN:PDF [20.10.2020]

19. Farkas, É. (2013). The Practice of Lifelong learning mobility tools in Hungary. Szeged: SZTE JGYPK 88 p.

20. Le Mouillour, I. (2012). Necessary Conditions for ECVET Implementation. Cedefop-European Centre for the Development of Vocational Training, Available: https://files.eric.ed.gov /fulltext/ED53 2257.pdf [18.05.2021]

21. Markowitsch, J., \& Hefler, G. (2019). Future developments in Vocational Education and Training in Europe: Report on reskilling and upskilling through formal and vocational education training (No. 2019/07). JRC Working Papers Series on Labour, Education and Technology, European Commission, Available: https://www. econstor.eu/bitstream/10419/231 331/1/jrcwplet201907.pdf [17.05.2021]

22. Poczmańska, A. \& Stęchły, W. (2020) Learning Outcomes and Their Assessment in Learning Mobility Projects. Catalogue of Examples. Foundation for the Development of the Education System, Warsaw 2020. 58 p. Available: https://depot.ceon. pl/handle/123456789/19133 [12.05.2021]

23. Szulc, W., Paduch, J., Zielinski, A., \& Dolezych, M. (2019) European Project 'Blueprint „New Skills Agenda Steel": Industry-driven Sustainable European Steel Skills Agenda and Strategy (ESSA)' Journal of Metallic Materials 2019, 71 (4), p. 2-11 DOI: 10.32730/imz.2657-747.19.4.1

24. The Bruges Communiqué (2010) The Bruges Communiqué on enhanced European Cooperation in Vocational Education and Training for the period 2011-2020, Belgian Presidency, Education \& Training 20 p. Available: https://www.cedefo p.europa.eu/files/bruges_en.pdf [15.10.2020]

25. Wiśniewski J., \& Zahorska M. (2020) Reforming Education in Poland. In: Reimers F. (eds) Audacious Education Purposes. Springer, Cham. https://doi.org/10.1007/978-3-030-41882-3_7 